\title{
Ameliorative Effects of Coffee Husk Compost and Lime Amendment on Acidic Soil of Haru, Western Ethiopia
}

\author{
Bikila Takala* \\ Ethiopian Institute of Agricultural Research, Jimma Agricultural Research Center, Jimma, Ethiopia
}

\begin{abstract}
A pot experiment was conducted to assess the effects of coffee husk compost, lime and their combinations on chemical properties of acidic soil and coffee seedling growth at Haru Research Sub-Center nursery site in west Wollega zone in 2016/17. Soil and coffee husk compost samples were collected, prepared and analyzed before and at the end of experiment following the standard laboratory procedures. The experiment was laid out in a factorial experiment arranged in Randomized Complete Block Design with three replications. The treatments included four levels of lime $(0,1.6,3.2$ and $\left.4.8 \mathrm{t} \mathrm{ha}^{-1}\right)$ and coffee husk compost $\left(0,5,10\right.$ and $\left.15 \mathrm{t} \mathrm{ha}^{-1}\right)$. The relevant soil data were collected and subjected to Analysis of Variance using SAS package and treatment means were compared at 0.05 probability using Duncan's Multiple Range Test. The results revealed that lime and coffee husk compost rates significantly increased the soil pH and decreased exchangeable acidity which resulted in improved nutrient availabilities of acidic soil. The highest values for soil chemical parameters such as organic carbon, total nitrogen, available phosphorus, cation exchange capacity and basic cations were obtained from the application of $15 \mathrm{t} \mathrm{ha}^{-1}$ coffee husk compost and combined lime and coffee husk compost at the modest levels of $3.2 \mathrm{t} \mathrm{ha}^{-1}$ lime and $10 \mathrm{t} \mathrm{ha}^{-1}$ coffee husk compost. From the study, it can be concluded that application of $15 \mathrm{t} \mathrm{ha}^{-1}$ compost or combining $10 \mathrm{t} \mathrm{ha}^{-1}$ of coffee husk compost and $3.2 \mathrm{t} \mathrm{ha}^{-1}$ of agricultural lime to acidic soil could be a promising alternative amendment for acid soil management and crop production in Haru areas, western Ethiopia.
\end{abstract}

\section{Keywords}

Amelioration, Coffee husk compost, Lime and soil acidity

\section{Introduction}

Soil acidity is among the major land degradation problems, which affects more than $50 \%$ of the world's potentially arable lands, particularly in the tropics and subtropics [1,2]. Most acidic soils have been found to be low in fertility, have poor chemical and biological properties. Strong soil acidity is mostly associated with $\mathrm{Al}, \mathrm{H}, \mathrm{Fe}, \mathrm{Mn}$ toxicities to plant roots in the soil solutions and corresponding deficiencies of the available plant nutrients such as calcium (Ca), magnesium (Mg), molybdenum (Mo), phosphorus $(P)$ and potassium $(K)[3,4]$.

In Ethiopia soil acidity and associated low nutrient availability are among major constraints to crop production and productivity [5-7]. Soil acidity is expanding both in scope and magnitude in the north -central, south western and western high lands of Ethiopia; severely limiting crop production and productivity [6-9]. Recently, Getachew, et al. [10] reported that about $43 \%$ of the cultivated land in humid and sub-humid highlands of Ethiopia are affected by soil acidity. Soil nutrient depletion, erosion and leaching of basic cations are also very widespread crop production constraint in Western Ethiopia. In the western part of the country particularly in eastern and western Wollega zones of Oromia, soil acidity was very critical and deserved immediate intervention to amend the soils for crop production and sustainable soil health management $[8,11,12]$.

Several practices have been recommended to reclaim acidity and upgrade the productivity of strongly acidic soils. These include the cultivation of acid tolerant crops, liming and the use of organic fertilizers. Of these practices, liming ameliorates soil acidity and reduces the detrimental effects of aluminum toxicity on nutrient availabilities and increase crop productivity $[13,14]$. However, it cannot be a permanent solution to the problem of soil acidity amelioration due to economic reasons particularly for smallholder farmers in developing countries such as Ethiopia [14] Therefore finding liming material from easily available organic materials is rec-

*Corresponding author: Bikila Takala, Ethiopian Institute of Agricultural Research, Jimma Agricultural Research Center, Jimma P. O. Box 192, Ethiopia

Accepted: November 24, 2020

Published online: November 26, 2020

Citation: Takala B (2020) Ameliorative Effects of Coffee Husk Compost and Lime Amendment on Acidic Soil of Haru, Western Ethiopia. J Soil Water Sci 4(1):141-150 
ommended where soil acidity is a serious threat to enhancing household and national food security.

Using compost and animal manures on crops almost always has the desirable effect since they contain substantial amounts of major and trace elements. Furthermore, they have a positive effect on the chemical and physical properties of the soil [15]. Thus, they can be of tremendous benefit in heavily weathered soils because they can improve the soil structure and its water holding capacity [16]. Also the need for renewable, locally available and cheaper options for supplying nutrient to crops is increasingly becoming important because of the need for sustainable agriculture $[15,17,18]$.

There is thus the need to recognize other potential organic amendment sources such as the by-products from wet and dry coffee processing. The dry coffee processing is commonly practiced and easily available at coffee producing areas in Haru areas of western Ethiopia [19]. These coffee by-products are utilized elsewhere as soil amendments [20-23]. While in south and western coffee producing areas of Ethiopia enormous quantities are either dumped into streams or burnt in big piles, with contributions to environmental hazards $[19,24-$ 26]. Therefore, the objective of this study were: To determine the effects of coffee husk compost and agricultural lime amendments on acidic soil and thus to contribute to sustainable soil fertility management and crop production system in western Ethiopia.

\section{Materials and Methods}

\section{Description of the study area}

The study was conducted at the Haru Agricultural Research Sub-Center (HARSC) in West Wollega zone, Oromia National Regional State, Western Ethiopia. Haru Agricultural Research Sub-center of the Jimma Agricultural Research Center was established in 1998 primarily to address the potentials and constraints in west Wollega specialty coffee growing areas. The center represents the sub-humid tepid to cool mid highlands coffee agro-ecological zone in West Ethiopia. It is found at 28 $\mathrm{km}$ from Gimbi town of west Wollega zone and $466 \mathrm{~km}$ from Addis Ababa in western Ethiopia. The area is geographically located between latitude of $8^{\circ} 54^{\prime} 30^{\prime \prime}$ North and longitude of $35^{\circ} 52^{\prime} 0^{\prime \prime}$ East at an elevation of 1750 m.a.s.l. The area is characterized by uni-modal rainfall pattern with an average annual rainfall of $1700 \mathrm{~mm}$. The rainy season starts in March or May and extends up to October. The mean maximum and minimum air temperature is $27.8^{\circ} \mathrm{C}$ and $12.4^{\circ} \mathrm{C}$, respectively. The soil type of the center is Acrisols and sandy clay loam [27].

\section{Experimental materials and procedures}

Fresh coffee husk was collected from the dry coffee processing site in Jitu town, Haru District. The compost was prepared by using $70 \%$ coffee husk, $20 \%$ animal manure and $10 \%$ forest soil to introduce beneficial microorganisms for decomposition following the procedure adopted by Solomon [24]. The prepared compost was air dried under shade, crushed, blended into powder and screened through $2 \mathrm{~mm}$ sieve and applied to the experiment.

Top soil at the depth of $0-20 \mathrm{~cm}$ was collected from open field which is less fertile and acidic soil to be amended with coffee husk compost and lime after air drying and screening through $2 \mathrm{~mm}$ sieve. Moreover, the different lime rates as powdered lime having a calcium carbonate equivalent of $98 \%$ was used. The lime requirement (LR) was obtained by multiplying Exchangeable acidity with soil depth $(0.20 \mathrm{~m})$, bulk density and crop factor [28].

$\mathrm{LR}, \mathrm{CaCO}_{3}(\mathrm{~kg} / \mathrm{ha})=(\mathrm{cmol} \mathrm{EA} / \mathrm{kg}$ of soil* $10000 \mathrm{~m}^{2 *} 0.20 \mathrm{~m}^{*}$ B.D $\left.\left(\mathrm{Mg} / \mathrm{m}^{3}\right)^{*} 1000\right) / 2000 * \mathrm{Cf}$

Where: $E A=3.2 \mathrm{cmol} \mathrm{kg}^{-1}$ of soil

B.D $=1.0 \mathrm{~g} \mathrm{~cm}^{-3}$

$\mathrm{Cf}$ (crop factor) $=1.5$ for moderately aluminum tolerant crops

Accordingly lime rate $(100,66.7,33.3$ and 0$) \%$ of lime requirement obtained from the above equation was used; which is $(4.8,3.2,1.6$ and 0$) \mathrm{t} \mathrm{ha}^{-1}$ respectively.

\section{Experimental treatments and design}

The treatments consisted of four coffee husk compost application rates $(0,6.25 \mathrm{~g}, 12.5 \mathrm{~g}$ and $18.7 \mathrm{~g})$ and four lime rates $(0,2 \mathrm{~g}, 4 \mathrm{~g}$, and $6 \mathrm{~g})$ in $2.5 \mathrm{~kg}$ of acidic soil; which is $(0,5,10$ and 15$)$ and $(0,1.6,3.2$ and 4.8$) \mathrm{t} \mathrm{ha}^{-1}$ coffee husk compost and lime rate respectively. The treatments were conducted using polythene bags of $12 \times 22 \mathrm{~cm}$ size. The polythene bags were prepared and firmly filled with the treatment rates which were added and thoroughly mixed with the soil.

A $4 \times 4$ factorial experiment arranged in a randomized complete block design with three replications was used for the study.

\section{Data Collection}

\section{Soil sample preparation}

The composite soil sample was prepared and analyzed for soil physical and chemical parameters at the beginning of the study. These included texture, $\mathrm{pH}$, exchangeable acidity (exchangeable $\mathrm{Al}^{3+}$ and $\mathrm{H}^{+}$ions), exchangeable cations $\left(\mathrm{Ca}^{2+}\right.$, $\mathrm{Mg}^{2+}, \mathrm{K}^{+}$and $\left.\mathrm{Na}^{+}\right)$, organic carbon, organic matter, total $\mathrm{N}$, available $\mathrm{P}$. Moreover, potting medium soil samples collected from each experimental unit and analyzed for some selected chemical properties after completing the experiment.

\section{Soil laboratory analyses}

The soil analyses were conducted at Jimma and Holetta Agricultural Research Center laboratory settings. The major soil physico-chemical parameters including soil texture, bulk density, soil reaction $(\mathrm{pH})$, exchangeable acidity, organic carbon, total nitrogen, available phosphorus, cation exchange capacity and potassium were determined at Jimma Agricultural Research Center, while basic cations ( $\mathrm{Ca}, \mathrm{Mg}$ and $\mathrm{Na}$ ), except K, were analyzed at Holetta Agricultural Research Center laboratory Table 1.

Soil texture was determined using Bouyoucos hydrometer [29]. Bulk density was estimated from undisturbed soil samples collected using core sampler following the method used 
Citation: Takala B (2020) Ameliorative Effects of Coffee Husk Compost and Lime Amendment on Acidic Soil of Haru, Western Ethiopia. J Soil Water Sci 4(1):141-150

by Blake [30]. Soil pH was measured potentiometrically using digital $\mathrm{pH}$ meter in 1:2.5 soil to water solution ratio [31]. Exchangeable acidity was determined by extracting the samples with $1 \mathrm{M} \mathrm{KCl}$ solution and titrating with $\mathrm{NaOH}$ as described by McLean. Cation exchange capacity (CEC) and exchangeable bases ( $\mathrm{Ca}, \mathrm{Mg}, \mathrm{K}$ and $\mathrm{Na}$ ) were determined after extracting the soil samples by ammonium acetate $\left(1 \mathrm{M} \mathrm{NH}_{4} \mathrm{O} \mathrm{Ac}\right)$ at $\mathrm{pH} 7.0$. Exchangeable $\mathrm{Ca}$ and $\mathrm{Mg}$ in the extracts were analyzed using Atomic Absorption Spectrophotometer (AAS) and $\mathrm{Na}$ and $\mathrm{K}$ were analyzed by flame photometer as described by Chapman [32] Organic carbon was determined following the wet digestion method [33] Organic matter content was calculated by multiplying the percent organic carbon by 1.724 . Total $N$ was determined by the Kjeldahil procedure [34]. Available P was determined by Olsen for compost sample [35] and Bray II for soil samples [36] extraction methods. The absorbance of available $\mathrm{P}$ extracted by both methods was measured using spectrophotometer after color development and the result were mentioned in Table 1.

\section{Statistical Analysis}

The collected soil data were summarized and subjected to ANOVA (analysis of variance) using SAS software (version 9.3) [37]. For significantly different treatments, the means were separated using Duncan's Multiple Range Test (DMRT) at ( $P$ $=0.05$ ). Simple correlation analyses were also conducted to assess the associations between some soil chemical parameters.

\section{Results and Discussion \\ Effects of coffee husk compost and lime amend- ments on soil pH and exchangeable acidity}

Analysis of variance revealed that soil $\mathrm{pH}$ and exchange-

Table 1: Selected physico-chemical properties of experimental soil and coffee husk compost.

\begin{tabular}{|c|c|c|}
\hline Physical and chemical properties & Soil & Coffee husk compost \\
\hline Sand (\%) & 64 & - \\
\hline Clay (\%) & 24 & - \\
\hline Silt (\%) & 12 & - \\
\hline Textural class & Sandy clay loam & - \\
\hline Bulk density $\left(\mathrm{g} / \mathrm{cm}^{3}\right)$ & 1.0 & - \\
\hline $\mathrm{pH}\left(\mathrm{H}_{2} \mathrm{O}\right)$ & 4.72 & 8.48 \\
\hline $\mathrm{pH}(\mathrm{KCL})$ & 3.72 & 7.01 \\
\hline Exchangeable acidity $\left(\mathrm{cmol}(+) \mathrm{kg}^{-1}\right)$ & 3.2 & - \\
\hline Organic carbon (\%) & 2.17 & 10.0 \\
\hline Organic matter (\%) & 3.74 & 17.3 \\
\hline $\mathrm{CEC}\left(\mathrm{cmol}(+) \mathrm{kg}^{-1}\right)$ & 11.35 & 65.52 \\
\hline Available phosphorus (mg kg-1) & 9.03 & 187.67 \\
\hline $\mathrm{Ca}\left(\mathrm{cmol}(+) \mathrm{kg}^{-1}\right)$ & 2.46 & 12.21 \\
\hline $\mathrm{Mg}\left(\mathrm{cmol}(+) \mathrm{kg}^{-1}\right)$ & 1.23 & 6.81 \\
\hline $\mathrm{K}\left(\mathrm{cmol}(+) \mathrm{kg}^{-1}\right)$ & 0.57 & 30.44 \\
\hline $\mathrm{Na}\left(\mathrm{cmol}(+) \mathrm{kg}^{-1}\right)$ & 0.05 & 1.13 \\
\hline $\mathrm{C}: \mathrm{N}$ ratio & 11.4 & 11.6 \\
\hline
\end{tabular}

Table 2: Interaction effects of coffee husk compost and lime rates on soil pH.

\begin{tabular}{|l|l|l|l|l|}
\hline Soil reaction $(\mathbf{p H})$ & \multicolumn{5}{l|}{} \\
\hline \multirow{2}{*}{$\begin{array}{l}\text { Lime rate } \\
\text { (t/ha) }\end{array}$} & Coffee husk compost rate $(\mathrm{t} / \mathrm{ha})$ & 10 & 15 \\
\hline 0 & 0 & 5 & $5.59^{\text {ef }}$ & $5.75^{\text {bcd }}$ \\
\hline 1.6 & $4.71^{\mathrm{h}}$ & $5.34^{\mathrm{g}}$ & $5.78^{\mathrm{abc}}$ & $5.87^{\mathrm{ab}}$ \\
\hline 3.2 & $5.31^{\mathrm{g}}$ & $5.49^{\mathrm{f}}$ & $5.79^{\mathrm{abc}}$ & $5.89^{\mathrm{ab}}$ \\
\hline 4.8 & $5.61^{\text {def }}$ & $5.65^{\text {cde }}$ & $5.81^{\mathrm{abc}}$ & $5.92^{\mathrm{a}}$ \\
\hline $\mathrm{CV}(\%)$ & $5.75^{\mathrm{bcd}}$ & $5.77^{\mathrm{abcd}}$ & & \\
\hline
\end{tabular}

Mean values within a row or column followed by the same letter(s) are not significantly different from each other at $\mathrm{P} \leq 0.05$ a,b,c,d,ef,f,h: : Indicate statistically significance difference of each treatment from each other at $5 \%$ by Duncan Multiple Range Test. 


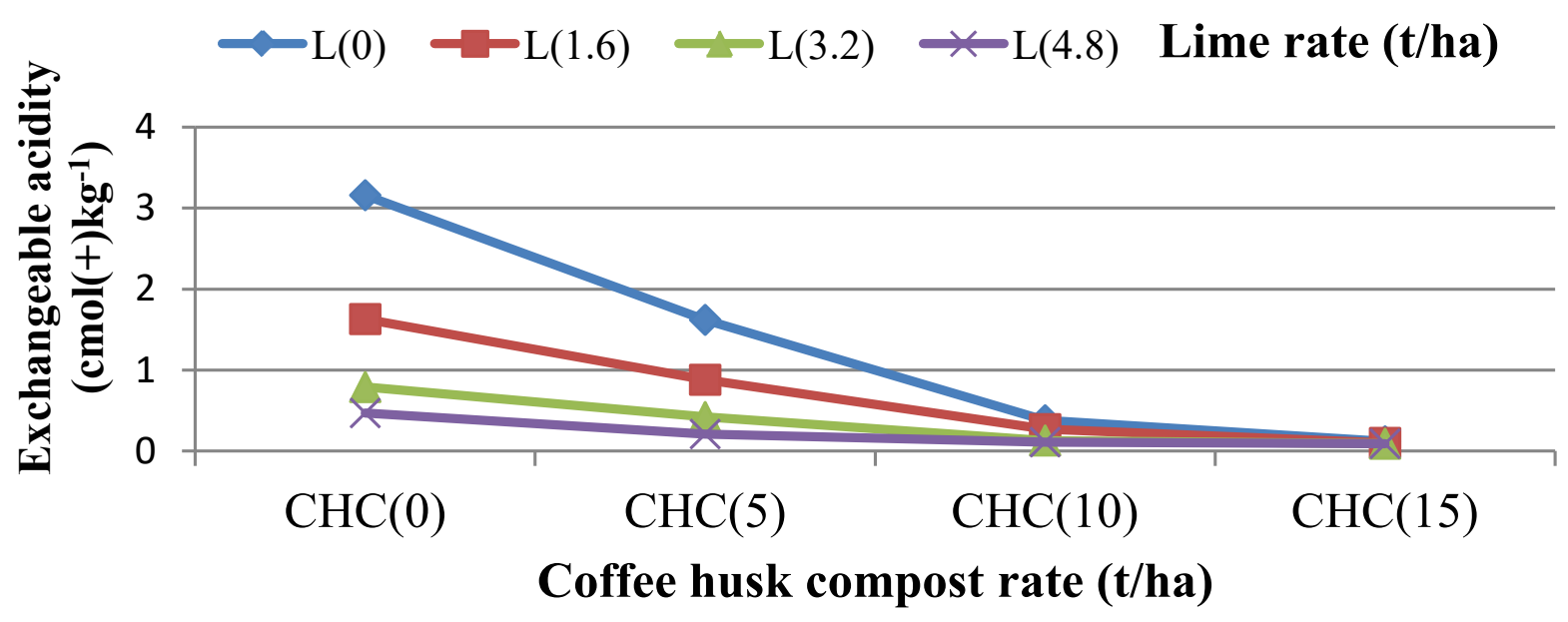

Figure 1: Interaction effects of coffee husk compost and lime rates on soil exchangeable acidity.

able acidity were highly significantly affected $(P<0.01)$ by application of lime, coffee husk compost and their combination (Table 2 and Figure 1). Accordingly, the lowest mean value (4.71) of $\mathrm{pH}$ was obtained from the control without any amendment while the highest value (5.92) was obtained from combined application of 4.8 lime and 15 coffee husk compost $\mathrm{t} \mathrm{ha}^{-1}$ (Table 2). Soil exchangeable acidity values also ranged from 3.16 to $0.09 \mathrm{cmol}^{(+)} \mathrm{kg}^{-1}$ for the same treatments (Figure 1).

Application of coffee husk compost alone showed change in soil pH from 4.71 (control) to 5.75 with level of $15 \mathrm{t} \mathrm{ha}^{-1}$ (Table 2). Hence, coffee husk compost alone has also an effect on soil pH since; it can contribute basic cations that neutralize soil acidity through hydrolysis reaction. Increase in soil pH due to the application of compost or organic amendments was also reported by Kasongo, et al. [20] and Fekadu, et al. [15].

The combination of lime with coffee husk compost mostly increased the soil $\mathrm{pH}$ than either lime or coffee husk compost alone (Table 2). The increase was attributed to the displacement of $\mathrm{Al}^{3+}$ and $\mathrm{H}^{+}$ions from soil sorption sites by $\mathrm{Ca}^{2+}$ content in lime. In addition, the $\mathrm{OH}^{-}$ions, $\mathrm{Ca}^{2+}$ and $\mathrm{Mg}^{2+}$ ions released through compost decomposition may have also contribute to the complexation of $\mathrm{Al}^{3+}$ and $\mathrm{H}^{+}$ions in the soil. Similar explanations were made by Gitari [38], Samake [39], Gitari, et al. [40] and Fekadu, et al. [15] who reported that application of lime combined with organic materials like manure increased soil $\mathrm{pH}$.

In all the treatments except the control, soil $\mathrm{pH}$ progressively increased while the exchangeable acidity decreased with increased rates of coffee husk compost and lime. This corroborates with the findings of Taye et al. [41], Kasongo, et al. [20,22], Nduka, et al. [23] and Bayu, et al. [42]. It could be attributed to reduction of $\mathrm{Al}^{3+}$ ions concentration in soil solution and in exchangeable sites because of lime and manure application [18]. Samake [39] and Tigist, et al. [18] also reported that addition of organic manures to acid soils increased soil $\mathrm{pH}$, decreased Al saturation, and there by improved conditions for plant growth.
Several mechanisms have been proposed for reducing acidity by organic manures. These mechanisms include specific adsorption of organic anions on hydrous Fe and Al surfaces and the corresponding release of hydroxyl ions which increase soil pH [43]. Adsorption of Al by organic matter sites and the subsequent isolation of the inorganic phase to maintain the equilibrium Al activity in soil solution have been proposed to increase soil $\mathrm{pH}$ [43].

Also the rise of soil $\mathrm{pH}$ through addition of compost could have been caused by consumption of $\mathrm{H}^{+}$by the humic-type substances which have a large number of carboxyl, phenolic functional groups $[15,20]$. These substances are formed during decomposition processes and are relatively stable against further decomposition. Their capacity to consume $\mathrm{H}^{+}$ therefore, indicates their buffer characteristics and their ability to neutralize soil acidity.

Gitari, et al. [40] found that additions of organic manures to acid soils improve soil fertility not only by adding organic matter and nutrients but also by increasing soil $\mathrm{pH}$ and decreasing concentrations of phytotoxic $\mathrm{Al}$ in exchangeable and/or soluble form. Certainly, the coffee husk compost used in this study had a higher $\mathrm{pH}$ than the study soil so their addition is likely to have contributed to the slight raise of $\mathrm{pH}$ of this soil (Table 1 and Table 2). The rise in $\mathrm{pH}$ and reduction of soil exchangeable acidity can also be associated with the presence of basic cation $\left(\mathrm{Ca}^{2+}\right)$ and anions $\left(\mathrm{CO}_{3}^{-2}\right)$ in lime that are able to exchange $\mathrm{H}^{+}$from exchange sites to form $\mathrm{H}_{2} \mathrm{O}+$ $\mathrm{CO}_{2}$ and cations occupy the space left behind by $\mathrm{H}^{+}$on the exchange leading to the rise in $\mathrm{pH}[3]$.

\section{Effects of coffee husk compost and lime amend- ments on soil organic carbon, total nitrogen and available phosphorus}

Soil organic carbon: The analysis of variance showed that soil organic carbon was significantly affected $(P<0.05)$ due to the application of coffee husk compost and lime (Table 3). Application of coffee husk compost caused increases in soil organic carbon from $2.12 \%$ (control plot) to $2.52 \%$ with application of $15 \mathrm{t} \mathrm{ha}^{-1}$ as shown in Table 3. This is about $24.75 \%$ 
Citation: Takala B (2020) Ameliorative Effects of Coffee Husk Compost and Lime Amendment on Acidic Soil of Haru, Western Ethiopia. J Soil Water Sci 4(1):141-150

Table 3: The interaction effects of coffee husk compost and lime rates on soil organic carbon and total nitrogen.

\begin{tabular}{|c|c|c|c|c|}
\hline \multicolumn{5}{|c|}{ Organic carbon (OC \%) } \\
\hline \multirow{2}{*}{$\begin{array}{l}\text { Lime rate } \\
\text { (t/ha) }\end{array}$} & \multicolumn{4}{|c|}{ Coffee husk compost rate (t/ha) } \\
\hline & 0 & 5 & 10 & 15 \\
\hline 0 & $2.12^{f}$ & $2.32^{\mathrm{bcd}}$ & $2.40^{\mathrm{ab}}$ & $2.52^{\mathrm{a}}$ \\
\hline 1.6 & $2.17^{\mathrm{ef}}$ & $2.35^{\mathrm{bcd}}$ & $2.41^{\mathrm{ab}}$ & $2.38^{\mathrm{bcd}}$ \\
\hline 3.2 & $2.27^{\text {de }}$ & $2.36^{\mathrm{bcd}}$ & $2.42^{\mathrm{ab}}$ & $2.39^{\mathrm{bc}}$ \\
\hline 4.8 & $2.28^{\text {cde }}$ & $2.37^{\mathrm{bcd}}$ & $2.41^{\mathrm{ab}}$ & $2.41^{\mathrm{ab}}$ \\
\hline CV (\%) & \multicolumn{4}{|l|}{3.60} \\
\hline \multicolumn{5}{|c|}{ Total nitrogen (TN \%) } \\
\hline 0 & $0.163^{\mathrm{g}}$ & $0.203^{\text {de }}$ & $0.203^{\text {de }}$ & $0.243^{a}$ \\
\hline 1.6 & $0.180^{f}$ & $0.217^{\text {cde }}$ & $0.210^{\text {cde }}$ & $0.237^{\mathrm{ab}}$ \\
\hline 3.2 & $0.193^{e f}$ & $0.203^{\mathrm{de}}$ & $0.223^{b c}$ & $0.220^{\mathrm{bcd}}$ \\
\hline 4.8 & $0.193^{\text {ef }}$ & $0.207^{\text {cde }}$ & $0.223^{b c}$ & $0.210^{\text {cde }}$ \\
\hline CV (\%) & \multicolumn{4}{|l|}{4.61} \\
\hline
\end{tabular}

Mean values within a row or column followed by the same letter(s) are not significantly different from each other at $\mathrm{P} \leq 0.05$ a,b,c,d,e,f,g:: Indicate statistically significance difference of each treatment from each other at $5 \%$ by Duncan Multiple Range Test.

increase over the control. The highest soil organic carbon recorded in soil amended with sole $15 \mathrm{t} \mathrm{ha}^{-1}$ of coffee husk compost was followed by combination of lime and coffee husk compost at the rate of $3.2 \mathrm{t} \mathrm{ha}^{-1}$ and $10 \mathrm{t} \mathrm{ha}^{-1}$ respectively which was increased $19.8 \%$ over the control. The increases in soil organic carbon content with the respective rates of coffee husk compost, clearly indicate contribution of the amendment to soil organic carbon content. Hence, the high organic carbon contents of the plot treated with coffee husk compost alone could be attributed to its high organic matter content. This corroborates with the works of Taye, et al. [41]. Samake, et al. [39] also reported increases in soil organic carbon content with increasing rates of organic matter amendments.

Even though statistically not significant, application of lime alone slightly increased soil organic carbon with increasing rates (Table 3 ). The magnitude of increment was in the range of $2.4-7.5 \%$ over the control with respective rates. The increment in soil organic carbon contents due to lime application, might be associated with the improvement of soil structure, which might be increased the stability of clay assemblages and clay-organic matter bonds, which should bring an increase in soil organic carbon physical and physicochemical protection.

Soil total nitrogen: Total soil nitrogen significantly $(P<$ 0.01 ) affected due to the main effect of coffee husk compost and interaction of lime and coffee husk compost. However, the main effect of lime did not significantly affected $(P>0.05)$ soil total nitrogen (Table 3 ). Compared to the control, all treatments increased nitrogen content of the soil (Table 3 ). Application of lime alone increased total nitrogen from 10.43$18.4 \%$ over the control with increasing rate. Correspondingly, total nitrogen content of the soil was increased from 24.5- 49 $\%$ by application of coffee husk compost over the control with increasing rate. The highest total nitrogen was obtained from application of $15 \mathrm{t} \mathrm{ha}^{-1}$ coffee husk compost without lime(0 lime) followed by combined application of $1.6 \mathrm{t} \mathrm{ha}^{-1}$ lime and $15 \mathrm{t} \mathrm{ha}^{-1}$ coffee husk compost and $3.2 \mathrm{t} \mathrm{ha}^{-1}$ lime and $10 \mathrm{t} \mathrm{ha}^{-1}$ coffee husk compost with increment of $49 \%, 45.4 \%$ and $36.8 \%$ over the control respectively. While, the lowest was obtained from the control (Table 3). The observed increase in total nitrogen could be due to some amount of decomposition which might have occurred when coffee husk compost was added to soil and improvement of the organic matter content of the soil. This agrees with the result reported by Tigist, et al. [18], who reported application of vermicompost and lime on acid soil had significantly increased soil total nitrogen and organic carbon. Also, Bayu, et al. [42] reported highest mean value of organic carbon and total nitrogen with application of $15 \mathrm{t} \mathrm{ha}^{-1}$ of coffee husk biochar amendment on acid soil.

Soil available phosphorus: The main effect of both lime and coffee husk compost and their interaction highly significantly $(P<0.01)$ affected soil available phosphorus as compared to the control (Figure 2). Application of lime without coffee husk compost increased available phosphorus content of the soil by 20.6-90.9\% over the control plot with increasing lime rate (Figure 2). This might be due to increased soil $\mathrm{pH}$ as a result of lime application. Liming of acidic soils could increase soil $\mathrm{pH}$, which enhances the release of phosphate ions fixed by $\mathrm{Al}$ and Fe ions into the soil solution $[11,15]$. The correlation analysis of the results also indicated significant, positive relationship between soil $\mathrm{pH}$ and available phosphorus of soil ( $r=0.67 ; \mathrm{P}<0.01$ ) (Table 4$)$. This clearly shows significant effect of soil pH on availability of phosphorus in acid soils.

Similarly, application of coffee husk compost significantly increased soil available $P$ relative to the control. The increases in available phosphorus due to coffee husk compost application were $154.5 \%$ at $5 \mathrm{t} \mathrm{ha}^{-1}, 298.5 \%$ at $10 \mathrm{t} \mathrm{ha}^{-1}$ and $480.9 \%$ at the application of $15 \mathrm{t} \mathrm{ha}^{-1}$ over control. The highest values of available phosphorous was recorded after application of $15 \mathrm{t} \mathrm{ha}^{-1}$ coffee husk compost without lime at $\mathrm{pH}$ of 5.75. The 


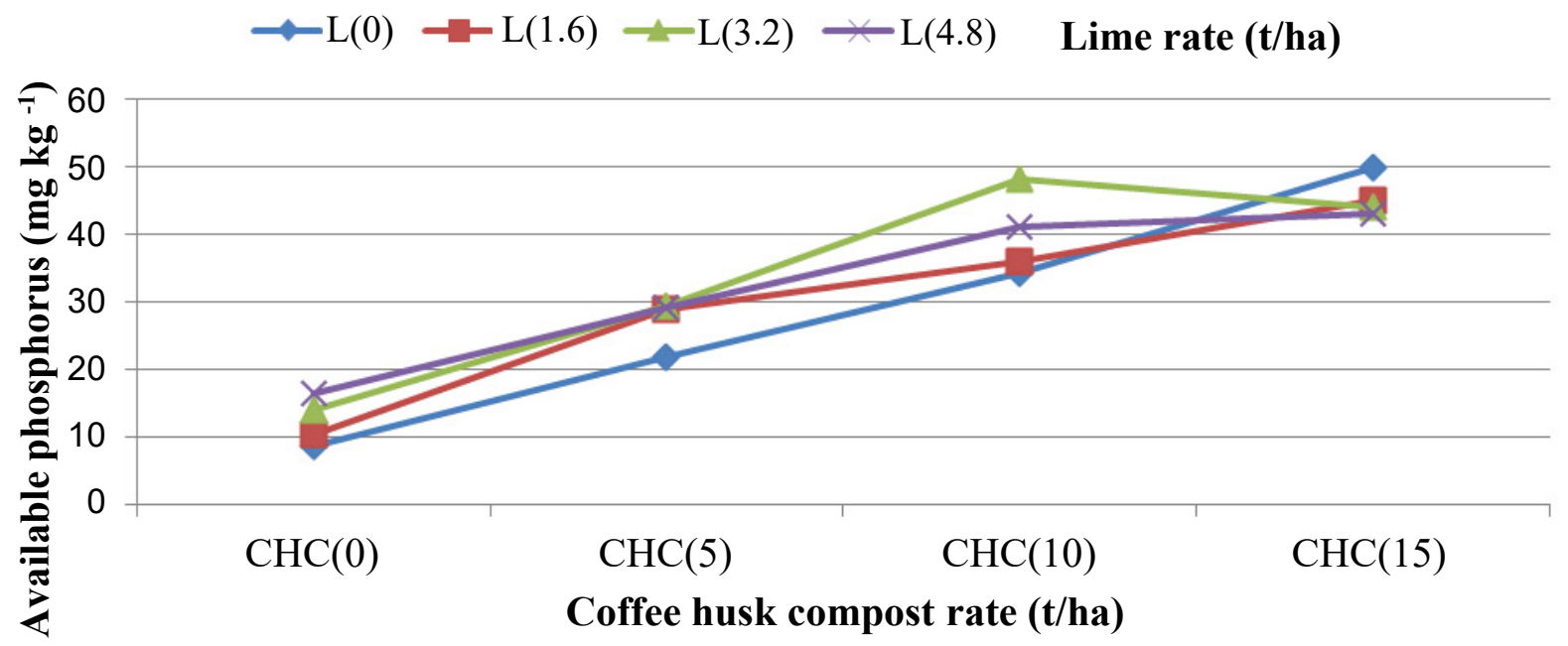

Figure 2: Interaction effects of coffee husk compost and lime rates on soil available phosphorus.

Table 4: Pearson correlation coefficients among some soil chemical properties $(n=48)$.

\begin{tabular}{|c|c|c|c|c|c|c|c|c|c|c|}
\hline & $\mathrm{pH}$ & Ex.A & OC & TN & Av.P & CEC & Ex.Ca & Ex.Mg & Ex.K & Ex.Na \\
\hline $\mathrm{pH}$ & 1 & & & & & & & & & \\
\hline Ex.A & $-0.93 * *$ & 1 & & & & & & & & \\
\hline OC & $0.75^{* *}$ & $-0.74 * *$ & 1 & & & & & & & \\
\hline TN & $0.69 * *$ & $-0.71 * *$ & $0.64^{* *}$ & 1 & & & & & & \\
\hline Av.P & $0.68^{* *}$ & $-0.75 * *$ & $0.61 * *$ & $0.82 * *$ & 1 & & & & & \\
\hline CEC & $0.81 * *$ & $-0.82 * *$ & $0.73 * *$ & $0.84^{* *}$ & $0.91 * *$ & 1 & & & & \\
\hline Ex.Ca & $0.78^{* *}$ & $-0.77 * *$ & $0.48 * *$ & $0.37 * *$ & $0.43^{* *}$ & $0.60 * *$ & 1 & & & \\
\hline Ex.Mg & $0.72 * *$ & $-0.78^{* *}$ & $0.51^{* *}$ & $0.67^{* *}$ & $0.88^{* *}$ & $0.87 * *$ & $0.68 * *$ & 1 & & \\
\hline Ex.K & $0.54^{* *}$ & $-0.63^{* *}$ & $0.59 * *$ & $0.72 * *$ & $0.85^{* *}$ & $0.76^{* *}$ & $0.18 n s$ & $0.63^{* *}$ & 1 & \\
\hline Ex.Na & $0.45 * *$ & $-0.33^{*}$ & $0.34 * *$ & $0.25 \mathrm{~ns}$ & $0.29 *$ & $0.40^{* *}$ & $0.31^{*}$ & $0.27^{*}$ & $0.33^{*}$ & 1 \\
\hline
\end{tabular}

Ex.A = Exchangeable Acidity; $O C=$ Organic Carbon; TN = Total Nitrogen; Av.P = available Phosphorus; $C E C=$ Cation Exchange Capacity; Ex.Ca = Exchangeable Calcium; Ex.Mg = Exchangeable Magnesium; Ex.K = Exchangeable Potassium; Ex $\cdot \mathrm{Na}=$ Exchangeable Sodium; PBS $=$ Percent Base Saturation; $n s=$ non-significant; ${ }^{*}=$ significant at $p \leq 0.05 ; * *=$ highly significant at $p \leq 0.01$.

observed increase in available phosphorus could be due to the presence of phosphorous in the coffee husk compost. It was suggested by Nduka, et al. [23], further decomposition of coffee husk could release organic substances that can form complex with ions of $\mathrm{Fe}$ and $\mathrm{Al}$ in soil solution consequently prevents phosphorus fixation. This gradually neutralizes soil acidity and hence makes fixed phosphorus available in the soil solution. This result was in agreement with Bayu, et al. [42] who reported increased soil available phosphorus with application of coffee husk biochar. Therefore, application of coffee husk compost to acid soil could increase available phosphorus contents of soil through releasing of phosphorus in it and also by increasing soil pH which reduces phosphorus fixation.

The combined application rate of $3.2 \mathrm{t} \mathrm{ha}^{-1}$ lime and $10 \mathrm{t}$ ha $^{-1}$ of coffee husk compost also caused an increase of available phosphorus contents of the soil by $462.4 \%$ over the control which is statistically par with the highest result obtained from $15 \mathrm{t} \mathrm{ha}^{-1}$ coffee husk compost (Figure 2). This result is in accordance with Tigist, et al. [18] who reported that com- bined application of lime and vermicompost significantly increased soil available phosphorus.

As it was discussed above, combined application of lime and coffee husk compost created favorable environment for microbial activities and possibly resulted in net mineralization of the applied soil which could enhance the release of available phosphorus. Availability of phosphorus is enhanced in an acid soil following the application of organic amendments $[18,22,23,39]$.Similarly Habtamu [44] reported organic matter as one of the most important and easily available reclamation methods for phosphorus fixation by blocking or chelating acidic cations, rising $\mathrm{pH}$ and negative charges, solubilizing and mineralizing nutrient phosphorus by organic acids and phosphatase enzymes. The post experiment higher residual quantity of phosphorus seems to inform that the coffee husk compost has adequate nutrient composition. Therefore the compost prepared from coffee husk may also be a very important liming material for soil acidity amelioration as reported by Nduka, et al. [23]. 


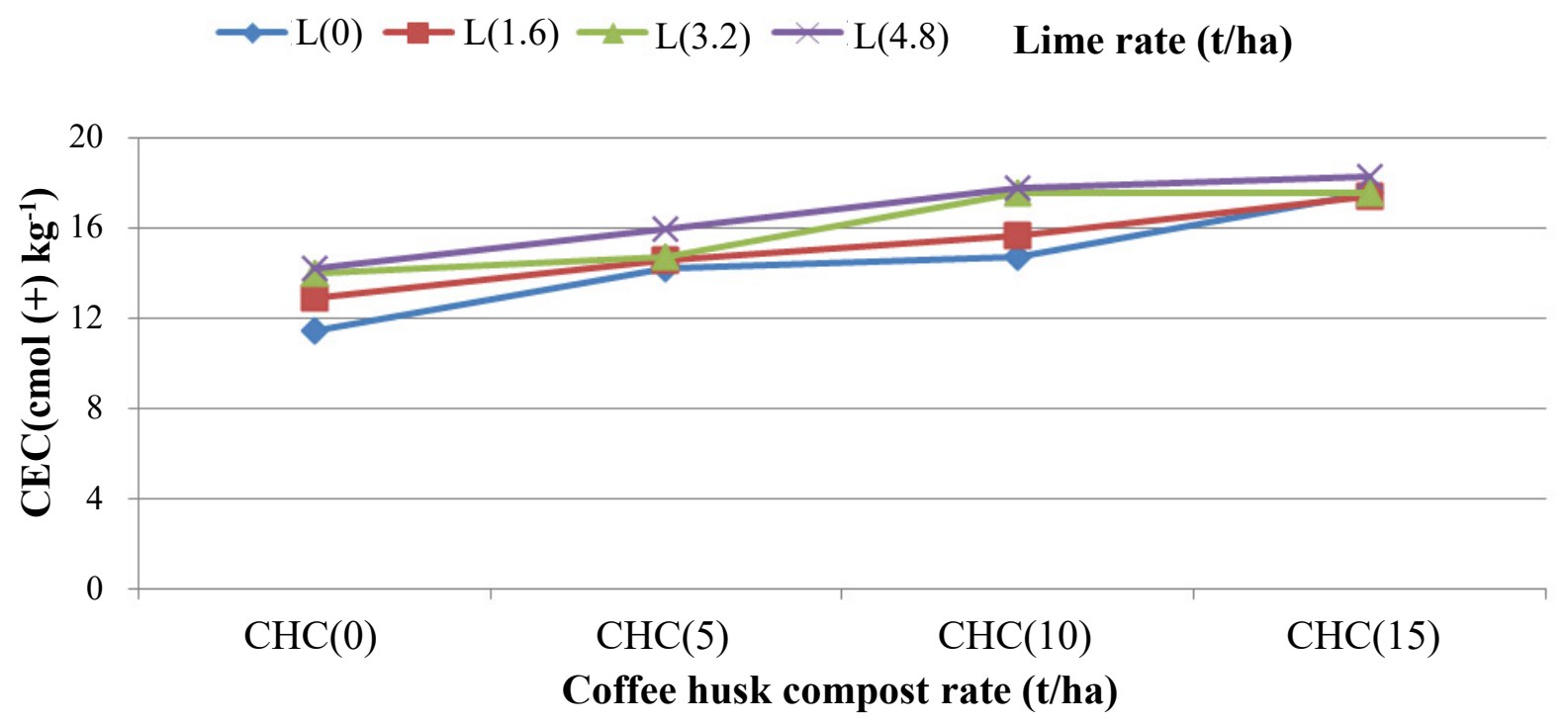

Figure 3: Interaction effects of coffee husk compost and lime rates on soil cation exchange capacity.

\section{Effects of coffee husk compost and lime amend- ments on soil cation exchange capacity and ex- changeable bases}

Soil cation exchange capacity (CEC): Analysis of variance revealed that soil CEC was highly significantly affected $(\mathrm{P}<$ 0.01 ) by the main effect of both lime and coffee husk compost and their interactions (Figure 3). Lime application without coffee husk compost increased CEC of soil with respective of levels (Figure 3). Accordingly the magnitude of increments for the soil treated with lime was $24.2 \%$ over the control plot with the highest lime rate $\left(4.8 \mathrm{t} \mathrm{ha}^{-1}\right)$. Similarly coffee husk compost application without lime also increased soil CEC with about $53.7 \%$ over the control with the highest compost rate $\left(15 \mathrm{t} \mathrm{ha}^{-1}\right)$. However the highest soil CEC $\left(18.28 \mathrm{cmol}(+) \mathrm{kg}^{-1}\right)$ was recorded for soils from plots treated with combined application of lime and coffee husk compost at the rates of 4.8 t ha ${ }^{-1}$ and $15 \mathrm{t} \mathrm{ha}^{-1}$ respectively with about $59.6 \%$ increment over the control while the lowest $(11.45 \%)$ was obtained from the control. This might be due to improved soil conditions such as soil pH and reduction of exchangeable acidity which in turn increased the exchange sites of the soil. This result was in line with Tigist, et al. [18] who reported the increment of soil CEC with lime and vermi-compost amendment on acid soil.

The correlation analysis of the results also indicated significant, positive relationship between soil $\mathrm{pH}$ and $\mathrm{CEC}$ of soil $(r=0.81 ; p<0.01)$ (Table 4). This clearly shows significant effect of soil pH on CEC. Therefore, any management option that can improve soil pH could increase CEC of soil and subsequently soil fertility.

Soil exchangeable calcium $\left(\mathrm{Ca}^{2+}\right)$ : Analysis of variance on soil exchangeable calcium showed that highly significant difference $(P<0.01)$ due to the main effects of lime and coffee husk compost and significance difference $(P<0.05)$ due to their interaction (Table 5). Accordingly application of lime alone increased soil exchangeable Ca by $112.8-280.9 \%$ above the control with increasing lime rate (Table 5). Similarly application of coffee husk compost without lime increased soil exchangeable Ca by $44.4-138.5 \%$ above the control with increasing compost rate (Table 5). However the highest increase of $351.4 \%$ exchangeable $\mathrm{Ca}$ above the control was recorded for soil from plots treated with combined application of lime and coffee husk compost at the rates of 4.8 and $10 \mathrm{t}$ $\mathrm{ha}^{-1}$ respectively. While the lowest value was obtained from the control (without any amendments) (Table 5). Probably, this higher exchangeable $\mathrm{Ca}^{2+}$ content from the combination of lime and coffee husk compost might be attributed to the release of $\mathrm{Ca}^{2+}$ ions in lime through its dissolution and mineralization of the compost. This agrees with Tigist, et al. [18] who reported increase of exchangeable $\mathrm{Ca}$ after application of lime alone and combined with vermicompost at western Ethiopia. Similarly, Gitari [38] found significant increase in soil exchangeable $\mathrm{Ca}$ when lime applied to acidic soils with manure.

Several authors reported that combined application of organic matter such as manure, compost and vermicompost with liming improved the soil chemical properties: $\mathrm{pH}$, exchangeable $\mathrm{Ca}$ and microbial activity $[11,15,20,39]$. These interactive effects are clear in this study as it was found that soil exchangeable Ca was positively and significantly correlated to soil pH ( $r=0.77: p<0.01$ ) (Table 4). This indicates exchangeable $\mathrm{Ca}$ is much more affected by soil pH.

Soil exchangeable magnesium $\left(\mathrm{Mg}^{2+}\right)$ : Combined or individual application of lime and coffee husk compost highly significantly $(P<0.01)$ affected soil exchangeable Mg (Table 5$)$. The highest mean value in soil exchangeable $\mathrm{Mg}$ due to lime application was observed with application rate of $4.8 \mathrm{t} \mathrm{ha}^{-1}$ (45\%) over the control plot (Table 5). Similarly application of coffee husk compost alone also increased exchangeable $\mathrm{Mg}$ by $183.7 \%$ over the control with application rate of $15 \mathrm{t} \mathrm{ha}^{-1}$. However, the most effective increment in exchangeable $\mathrm{Mg}$ $\left(5.57 \mathrm{cmol}(+) \mathrm{kg}^{-1}\right)$ was recorded for soils from plots treated with combined application of lime with coffee husk compost 
Citation: Takala B (2020) Ameliorative Effects of Coffee Husk Compost and Lime Amendment on Acidic Soil of Haru, Western Ethiopia. J Soil Water Sci 4(1):141-150

Table 5: The interaction effects of coffee husk compost and lime on soil exchangeable bases $\left(\mathrm{Ca}^{2+}, \mathrm{Mg}^{2+}, \mathrm{K}^{+}\right.$and $\left.\mathrm{Na}^{+}\right)$.

\begin{tabular}{|c|c|c|c|c|c|}
\hline \multicolumn{2}{|c|}{ Treatment description } & \multicolumn{4}{|c|}{ Exchangeable bases } \\
\hline $\begin{array}{l}\mathrm{CHC} \\
\text { rate(t/ha) }\end{array}$ & $L$ rate $(\mathrm{t} / \mathrm{ha})$ & $\begin{array}{l}\mathrm{Ca}^{2+} \\
(\mathrm{cmol}(+) / \mathrm{kg})\end{array}$ & $\begin{array}{l}\mathrm{Mg}^{2+} \\
(\mathrm{cmol}(+) / \mathrm{kg})\end{array}$ & $\begin{array}{l}\mathrm{K}^{+} \\
(\mathrm{cmol}(+) / \mathrm{kg})\end{array}$ & $\begin{array}{l}\mathrm{Na}^{+} \\
(\mathrm{cmol}(+) / \mathrm{kg})\end{array}$ \\
\hline \multirow[t]{4}{*}{0} & 0 & $2.41^{\mathrm{g}}$ & $1.23^{\mathrm{h}}$ & $0.49^{h}$ & $0.053^{c}$ \\
\hline & 1.6 & $5.13^{e}$ & $1.49^{\mathrm{gh}}$ & $0.53^{h}$ & $0.067^{\mathrm{ab}}$ \\
\hline & 3.2 & $7.60^{d}$ & $1.62^{\mathrm{gh}}$ & $0.57^{\mathrm{h}}$ & $0.067^{\mathrm{ab}}$ \\
\hline & 4.8 & $9.18^{\mathrm{bc}}$ & $1.79^{\mathrm{fgh}}$ & $0.77^{\mathrm{gh}}$ & $0.067^{\mathrm{ab}}$ \\
\hline \multirow[t]{4}{*}{5} & 0 & $3.48^{f}$ & $1.88^{\mathrm{fg}}$ & $1.09^{\mathrm{ef}}$ & $0.070^{\mathrm{ab}}$ \\
\hline & 1.6 & $5.80^{\mathrm{e}}$ & $2.34^{\mathrm{ef}}$ & $1.04^{\mathrm{fg}}$ & $0.060^{\mathrm{bc}}$ \\
\hline & 3.2 & $8.26^{\mathrm{cd}}$ & $3.24^{\mathrm{cd}}$ & $0.99^{\mathrm{fg}}$ & $0.060^{\mathrm{bc}}$ \\
\hline & 4.8 & $10.00^{\mathrm{ab}}$ & $3.73^{c}$ & $0.97^{\mathrm{fg}}$ & $0.067^{\mathrm{ab}}$ \\
\hline \multirow[t]{4}{*}{10} & 0 & $4.97^{e}$ & $2.80^{\mathrm{de}}$ & $1.70^{\mathrm{b}}$ & $0.063^{\mathrm{ab}}$ \\
\hline & 1.6 & $7.27^{d}$ & $3.36^{\mathrm{cd}}$ & $1.45^{\mathrm{bcd}}$ & $0.073^{\mathrm{a}}$ \\
\hline & 3.2 & $8.94^{\mathrm{bc}}$ & $4.48^{\mathrm{b}}$ & $1.38^{\text {cde }}$ & $0.070^{\mathrm{ab}}$ \\
\hline & 4.8 & $10.88^{\mathrm{a}}$ & $4.95^{b}$ & $1.24^{\text {def }}$ & $0.067^{\mathrm{ab}}$ \\
\hline \multirow[t]{4}{*}{15} & 0 & $5.75^{e}$ & $3.49^{c}$ & $2.39^{\mathrm{a}}$ & $0.070^{\mathrm{ab}}$ \\
\hline & 1.6 & $7.74^{d}$ & $4.35^{\mathrm{b}}$ & $1.70^{\mathrm{b}}$ & $0.063^{\mathrm{ab}}$ \\
\hline & 3.2 & $9.18^{\mathrm{bc}}$ & $4.88^{b}$ & $1.63^{\mathrm{bc}}$ & $0.067^{\mathrm{ab}}$ \\
\hline & 4.8 & $9.98^{\mathrm{ab}}$ & $5.57^{a}$ & $1.75^{b}$ & $0.070^{\mathrm{ab}}$ \\
\hline \multicolumn{2}{|l|}{ DMRT (5\%) } & $*$ & $* *$ & $* *$ & $*$ \\
\hline CV (\%) & & 8.40 & 10.79 & 13.23 & 8.02 \\
\hline
\end{tabular}

DMRT = Duncan's Multiple Range Test; $C H C=$ coffee husk compost $\mathrm{L}=$ Lime; ${ }^{*}=$ significant at $\mathrm{p} \leq 0.05 ;{ }^{* *}=$ highly significant at $\mathrm{p} \leq 0.01 ; \mathrm{CV}$ $=$ Coefficient of Variation. Mean values followed by the same letters with in a column are statistically not different from each other at $p \leq 0.05$ $a, b, c, d, e, f, g, h$, : Indicate statistically significance difference of each treatment from each other at $5 \%$ by Duncan Multiple Range Test.

at the rates of 4.8 and $15 \mathrm{t} \mathrm{ha}^{-1}$ respectively while, the lowest value $\left(1.23 \mathrm{cmol}(+) \mathrm{kg}^{-1}\right)$ was obtained from control (Table 5). These findings are in agreement with Tigist, et al. [18] who reported increased exchangeable $\mathrm{Mg}$ in the soil where vermicompost was applied combined with lime. Kasongo, et al.[20] also reported increased exchangeable $\mathrm{Mg}$ in soil as a result of coffee waste application due to the release of $\mathrm{Mg}$ through decomposition. Samake [39] also found increased $\mathrm{Mg}$ in the soil as a result of applied manure either alone or combined with lime and attributed the increase to improved soil $\mathrm{pH}$, as was observed in this study.

In the current study, there was significant, positive relationship between soil $\mathrm{pH}$ and soil exchangeable $\mathrm{Mg}(\mathrm{r}=0.72$; $\mathrm{P}<0.01$ ) (Table 4), which shows the importance of soil pH improvement to enhance soil $\mathrm{Mg}$ availability. According to Samake [39], the availability of $\mathrm{Mg}$ in acid soils is reduced under low soil pH as the soil exchangeable sites are depleted of $\mathrm{Mg}$, creating an imbalance of these nutrients. Therefore, its increase may be a result of improved soil conditions (acidity) due to improved organic matter and application of lime.

Soil exchangeable potassium $\left(\mathbf{K}^{+}\right)$: Application of lime and coffee husk compost amendment alone and their combination showed highly significant effect $(P<0.01)$ on soil exchangeable $\mathrm{K}$ over the control (Table 5). Application of lime alone increased significantly soil exchangeable $K$ as compared to control treatment (Table 5). This result was in line with Samake [39] findings where the application of lime alone significantly affected soil exchangeable K. On the other hand, combined application of coffee husk compost and lime increased exchangeable $\mathrm{K}$ by $264.5 \%$ over the control with application rate of $1.6 \mathrm{t} \mathrm{ha}^{-1}$ lime and $15 \mathrm{t} \mathrm{ha}^{-1}$ coffee husk compost. However, the most effective increase was obtained from application of coffee husk compost alone $(2.39 \mathrm{cmol}(+)$ $\mathrm{kg}^{-1}$ ) of soil using $15 \mathrm{t} \mathrm{ha}^{-1}$ of coffee husk compost. This was probably due to the added $\mathrm{K}$ with coffee husk compost which released into the soil system due to decomposition and mineralization. The compost used in the current study had of 30 cmol (+) kg-1 exchangeable $\mathrm{K}$ (Table 1 ) content which might have added significant amounts of this nutrient to the soil. Other researchers $[20,22]$ reported increased soil exchangeable $\mathrm{K}$ when coffee waste was applied to tropical acid soils.

Soil exchangeable sodium $\left(\mathrm{Na}^{+}\right)$: The main effects of lime did not significantly affected $(P>0.05)$ soil exchangeable sodium. However the main effects of coffee husk compost and interaction effects with lime significantly affected $(P<0.05)$ soil exchangeable sodium (Table 5). Accordingly the highest value $\left(0.077 \mathrm{cmol}^{(+)} \mathrm{kg}^{-1}\right)$ was obtained from application of $15 \mathrm{t}$ $\mathrm{ha}^{-1}$ coffee husk compost without lime and followed by 0.073 $\mathrm{cmol}(+) \mathrm{kg}^{-1}$ ) which was obtained from combined application of $3.2 \mathrm{t} \mathrm{ha}^{-1}$ lime and $10 \mathrm{t} \mathrm{ha}^{-1}$ coffee husk compost; while the lowest value $\left(0.053 \mathrm{cmol}(+) \mathrm{kg}^{-1}\right)$ was obtained from the control (Table 5).This could be due to added $\mathrm{Na}^{+}$with coffee husk 
compost to the soil and reduced nutrient fixation with lime as a result of increase in $\mathrm{pH}$.

\section{Conclusion}

The effect of coffee husk compost and lime amendment on acid soil was investigated under nursery experiment. Accordingly findings of the study showed that, application of the coffee husk compost and lime rates and their interactions were significantly improved soil chemical properties by increasing soil $\mathrm{pH}$ and reduced exchangeable acidity, in a way that enhanced the availability of plant macronutrients. The highest values for soil chemical parameters such as organic carbon, total nitrogen, available phosphorus, cation exchange capacity and basic cations were obtained from the application of $15 \mathrm{t} \mathrm{ha}^{-1}$ coffee husk compost alone and combined application of lime ( $3.2 \mathrm{t} \mathrm{ha}^{-1}$ ) and coffee husk compost $\left(10 \mathrm{tha}^{-1}\right)$. Furthermore, the increased soil pH, because of the liming effect of coffee husk compost, brought about a significant increase in plant nutrient availabilities with substantial reduction of phytotoxic exchangeable Al. This is of particular importance as it indicates the value of coffee husk compost as an alternative amendments to ameliorate acid soils for smallscale farmers who cannot afford to regularly purchase lime and mineral fertilizers. Therefore application of $15 \mathrm{t} \mathrm{ha}^{-1}$ coffee husk compost or combining $10 \mathrm{t} \mathrm{ha}^{-1}$ of coffee husk compost with $3.2 \mathrm{t} \mathrm{ha}^{-1}$ of agricultural lime to acidic soil could be a promising alternative amendment for acid soil management and crop production in Haru area, western Ethiopia.

\section{Acknowledgments}

The authors gratefully acknowledge Ethiopian Institute of Agricultural research and Jimma University College of Agriculture and Veterinary Medicine for the financial support of the study.

\section{References}

1. Sumner ME, Noble AD (2003) Soil acidification. In: Rengel Z, Hand book of soil acidity. University of Western Australia, Perth, Western Australia, Australia, 1-28.

2. Kochian LV, Hoekenga OA, Pineros MA (2004) How do crop plants tolerate acid soils? Mechanisms of aluminum tolerance and phosphorous efficiency. Annu Rev Plant Biol 55: 459-493.

3. Fageria NK, Baligar VC (2008) Ameliorating soil acidity of tropical oxisols by liming for sustainable crop production. Advances in agronomy 99: 345-400.

4. Kisinyo PO, Opala PA, Gudu SO, et al. (2014) Recent advances towards understanding Kenyan acid soils for improved crop production. African Journal of Agricultural Research 9: 2397-2408.

5. Mesfin A (2007) Nature and management of acid soil in Ethiopia. Haramaya University, Ethiopia, 99.

6. Wassie H, Shiferaw B (2009) Mitigation of soil acidity and fertility decline challenges for sustainable livelihood improvement: Research findings from southern region of ethiopia and its policy implications.

7. Tamene L, Amede T, Kihara J, et al. (2017) A review of soil fertility management and crop response to fertilizer application in Ethiopia: Towards development of site- and context-specific fertilizer recommendation.International Center for Tropical Ag- riculture (CIAT) 86 .

8. Abdenna D, Negassa Ch, Tilahun G (2007) Inventory of soil acidity status in crop lands of central and Western Ethiopia. Utilization of diversity in land use systems: Sustainable and organic approaches to meet human needs, 9-11.

9. Eyasu E (2016) Soil of Ethiopian highlands: Geomorphology and properties. CASCAPE Project, 385.

10. Getachew A, Chilot $Y$, Teklu (2019) Soil acidity management. Ethiopian institute of agricultural research (EIAR), 56.

11. Chimdi A, Heluf G, Kibebew K, et al. (2012) Effects of liming on acidity-related chemical properties of soils of different land use systems in Western Oromia, Ethiopia. World Journal of Agricultural Sciences 8: 560-567.

12. Abdenna $D$ (2013) Evaluation of soil acidity in agricultural soils of smallholder farmers in South Western Ethiopia. Science, Technology and Arts Research Journal 2: 01-06.

13. Wassie H, Shiferaw B (2011) On-farm verification of lime and npk fertilizers effects on the tuber yield of irish potato (solanum tuberosum) on some acidic soils of Southern Ethiopia. Journal of the Dry lands 4: 283-288.

14. Legesse H, Dechassa NR, Gebeyehu S, et al. (2016) Growth and dry matter partitioning of common bean (Phaseolus vulgaris L.) genotypes as influenced by aluminum Toxicity. Journal of Experimental Agriculture International 14: 1-13.

15. Fekadu E, Kibret K, Bedadi B, et al. (2018) Organic and inorganic amendments on soil chemical properties at different period of incubation of acidic soil. Eurasian Journal of Soil Science 7: 273 $-283$.

16. Ano AO, Ubochi Cl (2007) Neutralization of soil acidity by animal manures: Mechanism of reaction. African Journal of Biotechnology 6: 364-368.

17. Ahmad R, A Naseer, ZA Zahir, et al. (2006) Integrated use of recycled organic waste and chemical fertilizers for improving maize yield. Int J Agric Biol 8: 840-843.

18. Tigist A, Lemma W, Tesfaye $F$ (2019) Soybean (Glycine max L.) Response to lime and vermicompost amelioration of acidic nitisols of assosa, north Western Ethiopia. International Journal of Plant \& Soil Science 27: 1-18.

19. Takala B (2019) Soil acidity and its management options in Western Ethiopia: A Review. Journal of Environment and Earth Science 9: 27-35

20. Kasongo R.K, Verdoodt A, Kanyankagote P, et al. (2011) Coffee waste as an alternative fertilizer with soil improving properties for sandy soils in humid tropical environments. Soil Use and Management 27: 94-102.

21. Dzung N A, Dzung T T, Khanh VTP (2013) Evaluation of compost for improving soil fertility and sustainable coffee production in rural central highland of Vietnam. Resources and Environment 3: $77-82$

22. Kasongo RK, Verdoodt A, Kanyankogote P, et al. (2013) Response of Italian ryegrass (Lolium multiflorum Lam.) to coffee waste application on a humid tropical sandy soil. Soil Use and Management 29: 22-29.

23. Nduka BA, Adewale DB, Akanbi OSO, et al. (2015) Nursery soil amendments for cashew seedling production: a comparative analysis of coffee husk and NPK. Journal of Agricultural Science 7: 111-122. 
24. Solomon Endris (2006) Accelerated composting of coffee processing by products: An organic option for soil fertility management in the coffee based cropping system of south western Ethiopia.1084-1089.

25. Gezahegne B, Fikre L, Mulatu W (2011) Exploring the suitability of coffee pulp compost as growth media substitute in greenhouse production. International Journal of Agricultural Research 6: 255-267.

26. Henok K, Tenaw W (2014) Evaluation of some additives on coffee residue (coffee husk and pulp) quality as compost, southern Ethiopia. International Invention Journal of Agricultural and Soil Science 2: 14-21

27. Zebene M, Wondwosen $\mathrm{T}$ (2008) Potentials and constraints of nitisols and acrisols. In: Girma Adugna, Bayetta Belachew; Tesfaye Shimber; Endale Taye and Taye Kufa, Coffee diversity and knowledge. proceedings of national workshop four decades of coffee research and development in Ethiopia, 14-17 August 2007, Addis Ababa (Ghion hotel), Ethiopia, 209-216.

28. Kamprath EJ (1984) Crop response to lime on soils in the humid tropics. In: Adams RE, Soil acidity and liming. Agronomy. Amer Soc of Agron, Madison, Wisconsin, USA, 348-368

29. Bouyoucos G J (1962) Hydrometer method improved for making particle size analysis of soils. Agron J 54: 464-465.

30. Blake GR (1965) Bulk density. Methods of Soil Analysis. Part I, Am Soc of Agron. Madison, USA, 374-399.

31. Page AL (1982) Methods of soil analysis. Part 2. Chemical and microbiological properties. Am Soc of Agron Madison, USA, 62-67.

32. Champan H D (1965) Cation exchange capacity by ammonium saturation. Methods of soil analysis. Agron. Part II, Am. Soc. of Agron. Madison, USA, 891-901.

33. Walkley A, Black IA (1934) An examination of the Degtjareff method for determining soil organic matter and a proposed modification of the chromic acid titration method. Soil Science 37: 29-38.
34. Jackson ML (1958) Soil chemical analysis. Englewood Clifs, NJ, Prentice Hall, 498.

35. Olsen SR, Cole CV, Watanab FS, et al. (1954) Estimation of available phosphorus in soils by extraction with Sodium Bicarbonate. U. S. D. A. Circ 939.

36. Bray RH, Kurtz LT (1945) Determination of total, organic and available forms of phosphorus in soils. Soil Sci 59: 36-45.

37. SAS Institute Inc (2011) SAS ${ }^{\circledR 9} 93$ Macro Language: Reference. Cary, NC.

38. Gitari HI, (2013) Lime and manure application to acid soils and their effects on bio-chemical soil properties and maize performance at Kavutiri-Embu.

39. Samake A (2014) Use of locally available amendments to improve acid soil properties and maize yield in the savanna zone of Mali. Soil science, 210.

40. Gitari HI, Mochoge BE, Danga BO (2015) Effect of lime and goat manure on soil acidity and maize (Zea mays) growth parameters at Kavutiri, Embu County- Central Kenya. Journal of Soil Science and Environmental Management 6: 275-283.

41. Taye K, Mesfin A, Paulos D (2003) Contribution of organic amendment to physico-chemical conditions of coffee nursery media, In: Tilahun A, Eylachew Z, Proceedings of the Sixth Conference of the Ethiopian Society of Soil Science (ESSS) on Challenges of Land Degradation to Agriculture in Ethiopia, Addis Ababa, Ethiopia, 25-40.

42. Bayu D, Dejene A, Alemayehu R, et al. (2017) Improving available phosphorus in acidic soil using biochar. Journal of Soil Science and Environmental Management 8: 87-94.

43. Wong MTF, Swift RS (2003) Role of organic matter in alleviating soil acidity. In: Z. Rengel, Handbook of Soil Acidity, University of Western Australia, Perth, Western Australia, Australia 337-358.

44. Habtamu A (2015) Reclamation of phosphorus fixation by organic matter in acidic soils (Review): Global Journal of Agriculture and Agricultural Sciences 3: 271 -278.

DOI: $10.36959 / 624 / 439$

Copyright: (C) 2020 Takala B. This is an open-access article distributed under the terms of the Creative Commons Attribution License, which permits unrestricted use, distribution, and reproduction in any medium, provided the original author and source are credited. 